\title{
The Carrying Capacity of Genuk Industrial Zone, Semarang
}

\author{
Sudanti a), Sudharto P. Hadi b), Sutikno ${ }^{\text {c), }}$ \\ Purwanto ${ }^{d}$
}

a) Doctorate Programme of Environmental Science, Diponegoro University, Semarang, Indonesia,

b) Professor in Environmental Science, Diponegoro University, Semarang, Indonesia

c) Professor in Geography, Gadjah Mada University, Yogyakarta, Indonesia

d) Professor in Chemical Engineering, Diponegoro University, Semarang, Indonesia

Received: April 4, 2013/Accepted: April 24, 2013

\section{Abstract}

The process of industrialization in developing countries such as Indonesia continues to show significant growth. Industrial sector's contribution to GDP continued to increase compared to the agricultural sector. Growth in Gross Domestic Product (GDP) in 2008 increased by $6.1 \%$ when compared to 2007 [1]. This condition also occurs in Central Java Province. In Central Java the GDP from the industrial sectors are on the first rank, followed by other sectors such as agriculture, trade, hotel, restaurant and services [2]. Industrial activity grows very rapidly, facilitated by industrial zones and estates. The seriousness of the government in developing the industrial zone is proven by the many positive impacts and benefits gained for the development of the surroundings areas. Some of the advantages are the spurring economic growth in the region, increasing the local revenue through local taxes, creating new jobs, increasing incomes of the local people, and encouraging the growth of the informal sectors. In light of population growth, the industrial zones could also reduce the flow of urbanization, especially for areas which are located in the suburban areas. As the jobs are available nearby, instead of working in the city, the villagers would opt to work in the industrial zones/estates. However, aside of th afore-mentioned positive impacts and benefits, the industrial zones also led to a variety of negative impacts. They are in the form of waste pollution and environmental damage caused by activities of various kinds of factories in the industrial zones. Such pollution can be in the form of air, water, soil, smoke, odour, vibration, noise pollution, traffic congestion and flood, which could degrade the quality of the environment.

This study was conducted in Genuk Industrial Zone Semarang, since Semarang is a metropolitan city that has several industrial zones and areas, including along the north coast. The development of the industrial areas and their activities have the impacts on pollution, including land, water and air. The purpose of this study is to identify the carrying capacity of Genuk Industrial Zone in Semarang and the method used in this research is positivistic methods, with quantitative analyses, and explanatory type of research. In regards to the land suitability, water potential and demands, energy used and waste capacity, this study suggests that the carrying capacity has been exceeded to support the sustainability of the region.

To maintain sustainability of the zone, various efforts should be taken to overcome the inhibiting factors such as high tide, flooding, land subsidence, inadequate drainage system and environmental pollution. In addition, there is a need to redesign the layout of the industrial buildings and to keep operating waste treatment and disposal facilities.

Keywords: carrying capacity, assimilative capacity, industrial pollution, sustainability.

\section{Introduction}

Odum $[3]$ asserted that the carrying capacity of the environment is the amount of population which could be supported by an ecosystem. Environmental capacity is interpreted as the maximum capacity that can carry the load of existing population [4]. On the other hand, Vitousek [5] expressed that appropriated carrying capacity is defined as the land needed to provide resources and absorb wastes. Intended land may be available now, or borrowed from the past or even of the future.The carrying capacity of an area can be decreased due to natural forces or human activities (pollutions, wasteful use of resources, etc), or it can be maintained and even enhanced through the management or application of technology [6]. Based on many previous definitions, we may draw the concept of carrying capacity of Genuk industrial zone which is defined as the maximum level of industrial activity that can be supported by the environment without causing serious or irreversible damage to its natural environment [7].

The gist of carrying capacity of an area is the area of land and water needed by the population within the area, to: 1) continuously provide all the resources that are to be consumed, and 2) to continuously provide the ability to absorb all the waste generated And carrying capacity could be estimated by its bioproductivity part of a region, zone, community or even household. Bioproductivity is the amount and rate of production which occur in a given ecosystem over a given time period.

Urban planning, which has been experiencing rapid change and often controlled by the capital owners (investor), and the spatial planning which is lacking of proper land use significantly, could as well influence the occurrence of environmental degradation and pollution [8]. For instance land use patterns that do not pay attention to the land suitability, and thus ignoring the environmental carrying capacity. Land use plan that is more market driven rather than considering the carrying capacity, may go beyond land use capabilities. The negative impacts of the ecological balance are in the forms of waste pollution and environmental damage caused by activities of various kinds of factories within the industrial zones. Empirical data showed such pollution could be in the forms of air, water, soil, smoke, odour, vibration, noise pollution, traffic congestion and flood, which could degrade the quality of the environment.

Those various conditions and problems give rise to the question: have the activities of Genuk industrial zone been exceeding its carrying capacity?

The Industrial Zone of Semarang is located in Genuk district, administratively located in the city of Semarang and consists of 13 villages. The boundary between the district and the city of Semarang is Babon river. By law number $5 / 1981$ on the Master Plan

* Corresponding author sudantieko@gmail.com 
of Semarang Municipality (1975-200o) and law number 02/1990, industrial zone in Genuk was established, covering five villages namely Terboyo Wetan, Trimulyo, Muktihardjo Lor, Gebangsari and Genuksari.

The study area constitutes of one among 16 districts in the city of Semarang. It is located between latitude $6^{\circ} 94^{\prime} \mathrm{S}$ and latitude $6^{\circ}$ $97^{\prime} \mathrm{S}$, and at longitude $110^{\circ} 44^{\prime} \mathrm{E}$ up to longitude $110^{\circ} 5 \mathrm{o}^{\prime} \mathrm{E}$. The overall area of Genuk District is 27.39 square kilometers [9], and the study site is located in Genuk, which has an area of 800 hectares (see Figure 1)

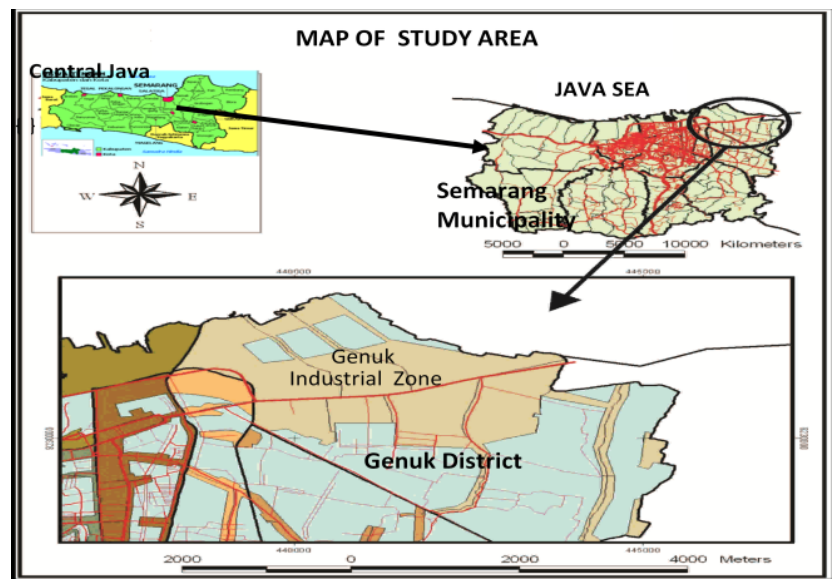

Figure 1 Map of The Study Area (Genuk Industrial Zone)

This research employs a positivism approach. This method belongs to a scientific method, since it complies with the scientific principles that are concrete/empirical, objective, measurable, rational and systematic. Nazir [10] found that the method of field research survey was conducted to obtain the facts of the existing symptoms and to seek factual particulars, both about social economic, or cultural of a group of people or a region.

In the analysis of the environmental carrying capacity, this research scrutinized the resources that are utilized by the industrial sectors such as land, water and energy potential, and the sinks or waste assimilative capacity. These indicators were chosen as these are the most important indicators which affected the evironmental balance at the most.The method used for land suitability assessment is a survey, overlayed maps. A purposive sampling method is utilized, and data analysis by scoring and weighting of 12 physical parameters of the land suitability for industrial zone [11], such as land slope, land slide, flood hazard, soil bearing capacity, drainage system, Coefficient of Linear Extensibility (COLE) index, soil texture classification, erosion, distribution of coarse materials, land subsidence, land disposition, and groundwater salinity. The COLE index is the ratio of difference between the moist length and dry length of a soil clod. The water potential capacity was evaluated by comparing potential water resources and water needs in the industrial zone and that include water as a raw material in industrial processes, cooling, flushing out wastes and so forth [10]. The energy footprint was obtained from secondary data of Regional electric company, 2012. The data is used to calculate the amount of capacity and electricity usage by the industrial zone. Then from these figures the carbon footprint was assessed. Environmental assimilative capacity was analyzed by utilizing water quality model. United States of Environmental Protection Agency (USEPA) has developed QUAL2E model as a tool to analyze Total Maximum Daily Loads (TDMLs) in the river or water bodies that have also been adopted by [13]. QUAL2E is a steady state and quasi-dynamic water quality model for the simulation of point source impact on water quality including nitrogen and phosphorus cycling, dissolved oxygen and BOD, algae, fecal coliform, other conservative and nonconservative substances flow.

\section{Results and Discussion}

\subsection{Land Suitability of Industrial Zone}

Based on the scoring and weighting results conducted on 12 physical parameters of land suitability for industrial zone, the value of suitability of land for industrial zone in the study area ranged between moderate and poor. Part of Genuk Industrial Zone which is located in the village of Trimulyo and Terboyo Wetan, have a poor category of land suitability (formerly was a swamp), and the village of Muktiharjo, Gebangsari and Genuksari with moderate levels of suitability. Terboyo Semarang Industrial Estate covering 287.64 hectares of poor land class. Industrial Estate of Terboyo Megah with an area of 43.15 hectares of moderate land class and $\mathbf{1 4 9 . 8 2}$ hectares covering poor land class. Bugangan Industrial Estate is located in an area of 101.281 hectares, has a poor category of land class. Pangkalan Truk Industrial Area, has an area of 18.72 acres with a moderate level of land class category and 94.5 acres of poor land class. The rest of $\mathbf{4 2 . 2 2}$ hectares have a moderate land class and poor land class category covering 53.62 hectares. The parameters that reduce the land suitability as well as hampering factors that need to be addressed are the high capacity of COLE index, medium grain-sized classification, slow drainage, soil bearing capacity, frequent floods, severe land subsidence, high sedimentation rate, and the high level of groundwater salinity. On the other hand, there are some supporting parameters of land in the region, such as a flat slope, minimum landslide danger, and evenly distribution of coarse material. However, in general, the poor values of physical parameters of land is so dominant that the land suitability classes of the industrial zone is considered as critical level. Figure 2 shows the map of land suitability of the zone.

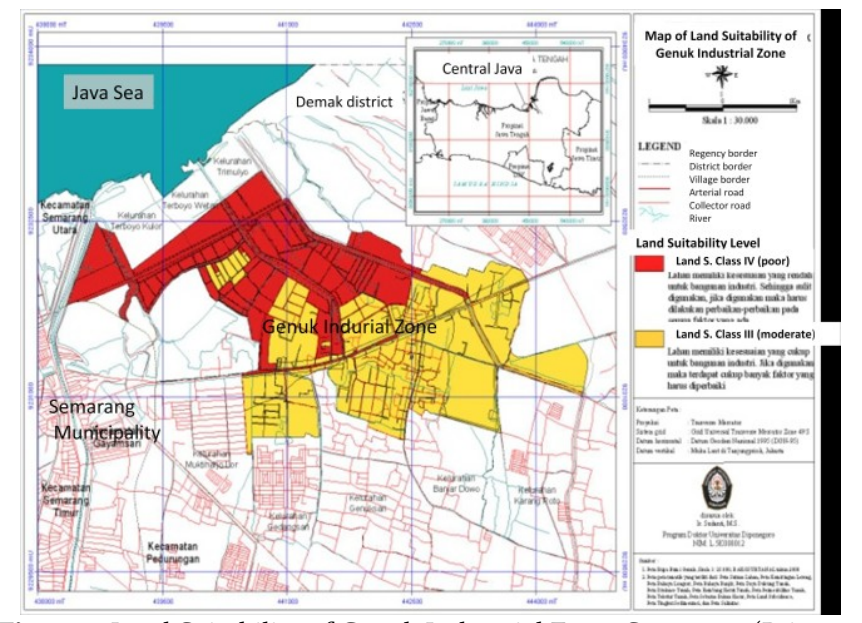

Figure 2 Land Suitability of Genuk Industrial Zone, Semarang (Primary data, 2013)

\subsection{Potential and Water Usage}

The availability of ground water in Genuk district is quite sufficient. Data sheet [14] showed that the area of groundwater basin (GWB) of Semarang-Demak is $1839 \mathrm{~km}^{2}$, with a potential in the form of unconfined aquifer groundwater 783 million $\mathrm{m}^{3} /$ year, and confined aquifer groundwater is 19 million $\mathrm{m}^{3} /$ year. Confined aquifers are permeable rock units or clay that are usually deeper under the ground than unconfined aquifers. Groundwater in a confined aquifer is under pressure and will rise up inside a borehole drilled into the aquifer. Unconfined aquifers is where groundwater in direct contact with the atmosphere through the open pore spaces of the overlying soil or rock.The upper groundwater surface in an unconfined aquifer is called the water table. The calculation of the potential GWB in the region of Genuk industry, based on the confined groundwater, is 683.225 .280 
liters/day. The potential is quite large compared to another ground water basin potential.The need for clean water in the industrial zone is supplied by artesian wells owned by industries. While a stand-alone industry need of clean water is filled from taps and part of the artesian well.

The capacity of the artesian wells is different for each industry, depending on their individual needs. Adapted from data on the number and type of industrial standards based on [15], the minimum water demand is 19.709 million liters of water/day, while the maximum water demand is 119538 ooo liters/day, and the middle value is equal to 75.88 million liters/day. This fact indicates that the water needs of industries in Genuk Industrial Zone of potential ground water basin Semarang-Demak is sufficient. However, given that the ground water basin in the District has declined Genuk groundwater from small to large category, ranging between -10 meters and -20 meters below sea level, it is necessary to monitor the decrease of depression in the District of Genuk [16]. As for the study, the groundwater in Genuk industrial zone is considered as the critical zone. It is a zone of thin aquifer with low productivity, low groundwater potential, and spread clustered mainly on the east coast of Semarang-Demak in the form of land subsidence.

\subsection{Energy Usage}

The calculation of the energy usage in the region of Genuk is limited to electricity demand, because the industries use electricity as source of power. The industry types in the region include furniture industries, garments, coal, thinner, coffe, warehouses, soap, fish fillet, advertising, stationery, ice cream, spring bed, wood, and plastic. Data [12] showed that Genuk Industrial Zone is supplied by 3 feeders (SYG 03, TBL o6 and TBL o7) as seen in Tabel 1

Tabel 1 Energy Supply for Industry (April-June), 2012

\begin{tabular}{|c|c|c|c|c|c|}
\hline \multirow[t]{2}{*}{ No } & \multirow[t]{2}{*}{ Feeder } & \multirow[t]{2}{*}{ Meter Device } & \multicolumn{3}{|c|}{ Month (kWh) } \\
\hline & & & April & May & June \\
\hline 1 & $\mathrm{SYG}_{3}$ & kWh EXIM & 2.645 .900 & 3.762 .440 & 4.387 .800 \\
\hline 2 & TBL 6 & $\begin{array}{l}\text { kWh } \\
\text { CUBICEL }\end{array}$ & & 5.784 .200 & 5.565 .600 \\
\hline \multirow[t]{4}{*}{3} & TBL 7 & $\begin{array}{l}\text { OUTGOING } \\
\text { kWH } \\
\text { CUBICEL } \\
\text { OUTGOING }\end{array}$ & $\begin{array}{l}5.500 .400 \\
4.470 .800\end{array}$ & 3.080 .100 & 3.046 .900 \\
\hline & Total & & 12.617 .100 & 11.355 .390 & 13.000 .300 \\
\hline & $\begin{array}{l}\text { Producti } \\
(\mathrm{kWh})\end{array}$ & Time (90\%) & 11.355 .390 & 11.364 .066 & 11.700 .270 \\
\hline & $\begin{array}{l}\text { Non Pro } \\
\text { (kWh) }\end{array}$ & tive Time & 1.261 .710 & 1.262 .6744 & 1.300 .030 \\
\hline
\end{tabular}

Table 1. shows that Genuk Industrial Zone is supplied from 3 feeders and the size of the installed capacity is $3 \times 480=1440$ Amperes [12]. The highest peak load (maximum load) is 1049 Amperes. With a total peak load of 1049 Amperes and 1440 Amperes installed capacity, the assignment is $72.84 \%$ or exceeding of $70 \%$. The use of electrical energy in Genuk industrial zone is approaching a critical threshold. The power load curve is shown in Figure 3.

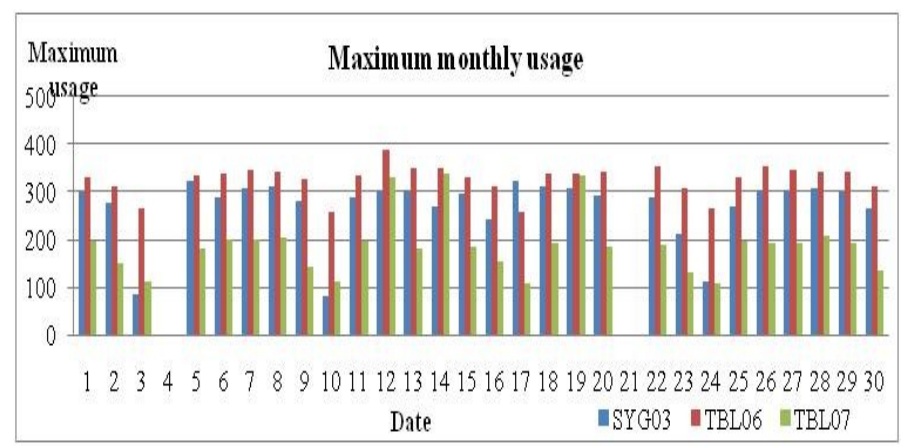

Figure 3 The Power Peak Load, 2012 (Regional Electricity Company, 2012)

To figure out the $\mathrm{CO}_{2}$ load towards the environ- ment, the amount of Carbon Footprint in Genuk Industral Zone was estimated as 116.964 tonnes of $\mathrm{CO}_{2} \mathrm{eq} /$ year or 146.2 tonnes of $\mathrm{CO}_{2}$ eq/year/ hectare. This amount is much higher than the carbon footprint of Rungkut Industrial Estate of Surabaya amounted to 13.628,16 tonnes $\mathrm{CO}_{2}$ eq/year or 41.29 tonnes of $\mathrm{CO}_{2}$ eq/year/hectare [17]. One of the reason is because Rungkut Industrial Estate is managed under one management of PT. SIER and has an integrated communal waste treatment plant.

\subsection{Waste Assimilative Capacity}

There are 3 rivers nearby Genuk Industrial Zone, namely Sringin, Tenggang and Babon river, but this study only estimates the assimilative capacity of the Babon river, since it is the largest river in the District and traverse across Genuk Industrial Zone. The analysis of assimilative capacity of the industrial zone is limited to the capacity of Babon river and the magnitude of liquid waste generation of industrial zone is examined from the BOD waste only, according to the Regulation of Water Pollution Load Capacity no. 110/2003.

Babon river has large water fluctuations with an average of small water discharge. By estimating the Total Maximum Daily Load (TMDL) between Karangroto and Industrial Complex segment on real condition / baseline to the target stream classes of 2-3, with streamflow minimum in August and the maximum river discharge in March, Babon river conditions still encounter overload pollutants, due to the large TMDL. Similarly, in the target class of Babon river at grade 3-4 (Regulation no.82/2001) in simulating conditions, the minimum streamflow in August, Babon river is still overloaded by BOD, since the TMDL is still smaller than the load of pollutants that enter the river, so the condition is still over-utilized in the river layer. Only under simulating conditions at the target class of grade 3-4 [18], at the maximum river discharge in March alone, Babon river are able to accept the load of BOD, since the TMDL is greater than the load of pollutants that enter the river (efficient utilization).

Based on the aspect of land suitability, potential and necessity of water, energy and pollution load capacity of industrial waste in Genuk Industrial Zone, the recapitulation of the potential carrying capacity of the environment in Genuk Industrial Zone Semarang is shown in Table 2. 
Table 2 Recapitulation of Carrying Capacity of Genuk Industrial Zone

\begin{tabular}{|c|c|c|c|c|}
\hline \multirow[t]{2}{*}{ No } & \multirow{2}{*}{$\begin{array}{l}\text { Components of Enviromental } \\
\text { Carrying Capacity }\end{array}$} & \multicolumn{3}{|c|}{ Level } \\
\hline & & $\begin{array}{c}\text { Good } \\
(+++)\end{array}$ & $\begin{array}{l}\text { Moderate } \\
(++)\end{array}$ & $\begin{array}{l}\text { Poor } \\
(+)\end{array}$ \\
\hline \multirow[t]{7}{*}{1} & $\begin{array}{l}\text { Supportive Capacity } \\
\text { a) Land: (slopes, land slides, } \\
\text { flood and tidal, soil bearing } \\
\text { capacity, erosion, drainage, } \\
\text { grain size, Cole index, abrasive } \\
\text { material distribution, land sud } \\
\text { sidence, groundwater level, } \\
\text { groundwater salinity) } \\
\text { b) Water }\end{array}$ & & 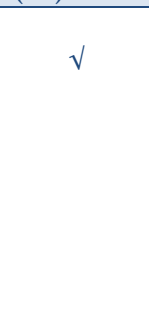 & $\sqrt{ }$ \\
\hline & - Potential & & $\sqrt{ }$ & \\
\hline & - Water needs & & & $\sqrt{ }$ \\
\hline & c) Energy (electricity) & & & \\
\hline & - Potential & & $\sqrt{ }$ & \\
\hline & - $\quad$ Usage & & & $\sqrt{ }$ \\
\hline & - Carbon footprint & & & $\sqrt{ }$ \\
\hline \multirow[t]{4}{*}{2} & Assimilative Capacity & & & \\
\hline & a) Contaminant load & & & $\sqrt{ }$ \\
\hline & $\begin{array}{l}\text { b) Waste capacity of BOD, COD } \\
\text { and DO }\end{array}$ & & & $\sqrt{ }$ \\
\hline & Conclusion & & & $\sqrt{ }$ \\
\hline
\end{tabular}

Referring to the above findings, as the dominance is at the level of moderate (3) and poor (6), it could be concluded that the environmental carrying capacity of Semarang Industrial Zone is poor.

\section{Results and Recommendations}

\subsection{Results}

1. The level of land suitability for industrial zone in the study area has been at the poor level. The limiting parameter for this area are routine flooding and tides, poor soil bearing capacity, poor drainage system, poor grain size classification, highcapacity of COLE index, high rate of land subsidence, high sedimentation rate, and high levels of ground water salinity.

2. The need of water for industries in the industrial zone supplied from groundwater basin of Semarang-Demak is sufficient. However, given that the ground water basin in the district has declined as the groundwater distressed is occurred by decreasing category of small to large, it is necessary to monitor the pressure drop in the sub district of Genuk and surrounding areas.

3. From the perspective of energy, the assignment has reached $72.84 \%$ or exceeding of $70 \%$. The usage of the electrical energy in Genuk Industrial Zone is approaching a critical threshold.

4. The carbon footprint of Genuk Industrial Zone is much higher than Rungkut Industrial Estate of Surabaya. One of the reason is because Rungkut Industrial Estate is managed under one management of PT. SIER and has an integrated communal waste treatment plant and incinerator.

5. The environmental carrying capacity in Genuk Industrial Zone, to be examined from the aspect of land, water, energy and waste assimilation is at the level of critical/ over- shoot.

\subsection{Recommendations}

Based on the conclusions above, the recommendations necessary for the development of Genuk industrial zones are as follows:

1. For sustainable planning of the industrial zone, besides the socio-economic aspects, the carrying capacity of the environment should be considered on the planning and monitoring of the industrial development, as mandated in the
Environmental Management Act No. 23 of 2009 and Law on Spatial Planning No. 26 of 2007.

2. In extracting ground water for industrial purposes, the condition of the existing groundwater basin should be considered. Given that the groundwater basin in the District has declined and distressed by decreased category of small to large, it is necessary to monitor the decrease in groundwater basin in Genuk and surrounding areas.

3. In terms of energy usage, it is suggested that the amount of carbon footprint ( $\mathrm{CO}_{2}$ emission) that burden the environment is quite severe. Such effort is necessary to be made to reduce the load by applying cleaner production system.

4. To reduce the BOD concentration that is contained in the Babon river. The development of cleaner production programs (Ecological Friendly Industry) is recommended which would lead to Eco-industrial park, tightening the quality standard of industrial wastewater discharge and increasing the average flow of Babon river by reducing land conversion and reforestation program of upstream watershed.

5. If this area is still to be developed, it takes a huge investment for structural intervention to overcome the obstacles caused by some parameters mentioned above, such as constructing an adequate drainage systems and other infrastructures development.

6. The concept of industrial carrying capacity can be applied and used as an evaluation tool. Industry will benefit from an understanding of the implications of corporate policies on the impotant of environmental carrying capacity. The carrying capacity accounting stimulates toward environmental initiatives in embracing the carrying capacity of such industrial zone/area.

\section{References}

[1] Central Bureau of Statistics, 2009.

[2] Regional Bureau of Statistics, 2007. Central Java in Figures, 2007.

[3] Odum, H.T, 1971. Environment, Power, and Society. John Wiley \& Sons, USA.

[4] Catton, W.R, 1986. Carrying capacity and the limits to freedom. Paper prepared for Social Ecology Session 1, Xl World Congress of Sociology. New Delhi, India.

[5] Vitousek P.M, Ehrlich P.R, Ehrlich A.H, Matson, P.A. 1986. "Human Appropriation of the Products of Photosynthesis," Bio Science, Vol. 36, No. 6. pp. 368-373. http://links.jstor.org/sici?sici=0oo6

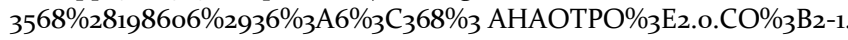

[6] Saveriades, A, 2ooo. "Establishing the Tourism Carrying Capacity for the Tourist Resorts. of the East coast of the Republic of Cyprus. Tourism Management 21: 147-156

[7] Sudanti, S., 2013. "Ecological Footprint Study of Genuk Industrial Zone of Semarang." Un- published dissertation of Doctorate Program of Environmental Science, Diponegoro Uni- versity Semarang

[8] Hadi, S., 2005, "Environmental Dimensions of Development Planning", Gadjah Mada University Press, Yogyakarta.

[9] Development Planning Agency (Bappeda) Semarang, 2008. "Final Report BWK IV (Genuk), Revised Document Details City Spatial Plan (RDTRK) Semarang City".

[10] Nazir, M, 1983. Research Methods. Publisher GI, Darussalam.

[11] Ministry of Public Works number : 20 / PRT/M/2007/M/2007. Technical Guideline of Physical Aspects and Analysis of Environment Economic, Social and Cultural in Spatial Planning, 2007.

[12] Regional Electricity Company, 2012.

[13] Decree of State Minister of the Environment number 110/2003 about Guidelines for Determining Load Capacity of Water Pollution in Water Resources.

[14] Ministry of Energy and Mineral Resources, 2011. Presidential Decree No. 26 Year 2011 on Determination of Ground Water Basin (GWB) of Indonesia, Jakarta.

[15] National Bureau of Standards, Preparation of Balance Resources - Part I: Balance of Resources-Part 1: Water Resources Spatial. Indonesian National Standard (SNI), 19-6728.1-2002. 
[16] Sriyono, S., Qudus, N., Setyowati, D.L., 2008. "Groundwater Availability Model Spatial and Sea Water Intrusion on Soil Conservation Zoning," UNNES Semarang.

[17] Setiawan, RJ, Boedisantoso, R., and M. Razif "Carbon Footprint Assessment of Industrial Activity in Surabaya." Laboratory of the Air Pollution Control Department of Environmental Engineering FTSP ITS Surabaya. http://digilib. its.ac.id/public/ITS-14136-paperpdf.pdf

[18] Indonesian Government Regulation No. 82 Year 2001 on Management of Water Quality and Water Pollution Control. 